\title{
MADRASAH INFRASTRUCTURE MANAGEMENT BEFORE FACE-TO-FACE LEARNING IN THE PANDEMIC
}

\author{
Sundaniawati Safitri ${ }^{1}$, Sri Mulyati ${ }^{2}$, Wahyudi ${ }^{3}$, Maftuhah ${ }^{4}$, Zahruddin ${ }^{5}$ \\ Islamic Educational Management Department, Universitas Islam Negeri Syarif Hidayatullah \\ Jakarta, Indonesia
}

Email: sundaniawati.safitri20@mhs.uinjkt.ac.id ${ }^{1}$, sri.mulyati20@mhs.uinjkt.ac.id², wahyudi20@mhs.uinjkt.ac.id³, maftuhah@uinjkt.ac.id ${ }^{4}$, zahruddin@uinjkt.ac.id ${ }^{5}$

\begin{tabular}{|c|c|c|}
\hline Received: April 2021 & Accepted: July 2021 & Published: August 2021 \\
\hline
\end{tabular}

\begin{abstract}
:
This current study aimed to analyze and comprehend the management of the madrasa's facilities and infrastructure to hold face-to-face learning during the Covid19 pandemic. This study was conducted at MI Soebono Mantofani, which is located in Ciputat, South Tangerang. The study employed a descriptive approach with qualitative methods. Data were obtained through interviews, observation, and documentation. The data analysis technique in this study followed the procedures: data reduction, data presentation, conclusion drawing, and verification. The study results highlighted the importance of needs analysis before preparing facilities and infrastructure planning policy to procure facilities and infrastructure by available safety procedures. Besides, the school management system also endorsed the principal's critical role in preparing the recipes, organizing the facilities during faceto-face learning, and holding the maintenance process accountable. This study also provided implications for managing the facilities and infrastructure amidst pandemics and hopefully shed some light on other relevant stakeholders in facing the upcoming face-to-face learning in the middle of the pandemic.
\end{abstract}

Keywords: COVID-19, Infrastructure Management, Face-to-face Learning

Abstrak:

Penelitian ini bertujuan untuk menganalisis dan memahami manajemen sarana dan prasarana madrasah menjelang pembelajaran tatap muka di masa pandemi Covid-19. Penelitian ini dilakukan di MI Soebono Mantofani yang berlokasi di Ciputat, Kota Tangerang Selatan. Penelitian menggunakan pendekatan deskriptif dengan metode kualitatif. Data diperoleh melalui wawancara, observasi, dan dokumentasi. Teknik analisis data dalam penelitian ini mengikuti prosedur sebagai berikut: reduksi data, penyajian data, penarikan kesimpulan dan verifikasi. Hasil dari penelitian ini menyoroti pentingnya analisis kebutuhan sebelum menyusun kebijakan perencanaan sarana dan prasarana di sekolah agar pengadaan sarana dan prasarana sesuai dengan prosedur keselamatan yang ada. Selain itu, sistem manajemen sekolah juga mendukung peran kunci kepala sekolah untuk mempersiapkan prosedur dalam mengatur fasilitas selama pelaksanaan pembelajaran tatap muka dan memastikan proses pemeliharaan dapat dipertanggungjawabkan. Kajian ini juga memberikan beberapa implikasi dalam pengelolaan sarana dan prasarana di tengah pandemi dan diharapkan dapat memberikan pencerahan bagi pemangku kepentingan terkait lainnya dalam menghadapi pembelajaran tatap muka di tengah pandemi mendatang.

Kata Kunci: COVID-19, Manajemen Sarana Prasarana, Pembelajaran Tatap Muka 


\section{INTRODUCTION}

After a year of combatting the pandemic, Indonesia is now preparing to face the era called Adaptasi Kebiasaan Baru (AKB) or Adaptation to the New Normal, where people are allowed to carry out their activities amid an outbreak while still complying with health protocols. A gradual easing of activity restrictions is carried out to restore normal activities and rebuild all life sectors. One of the government's policies in AKB is to reopen schools/madrasas and reimplement face-to-face learning.

The reopening of madrasas has undoubtedly been a long wait by relevant stakeholders. Of course, it becomes pivotal because the longer the madrasas are closed, the greater the possibility of negative impacts, including the vulnerability of disadvantaged children to the risk of dropping out of school, laziness that hurts peers, and involvement of children in crime (Onyema et al., 2020). Levinson, Cevik, and Lipsitch (2020) explain that if children do not do face-to-face learning for a very long time, they will lose interest in academic learning, social-emotional relationships, relationships with peers and adults, opportunities to play, and other developmental needs when they are only learning from home.

Nadiem Makarim, through the Ministry of Education and Culture's youtube channel, stated that in July 2021, schools/madrasas might carry out face-to-face learning as long as meeting the required conditions set by the government. These requirements consist of five points, namely; 1) Permission of three stakeholders, namely the Regional Government / Regional Office / Ministry of Religion, school principals, and parents' representatives through the school committee; 2) Fulfillment of a checklist of educational facilities that comply with standards; 3) We are implementing Health protocols strictly; 4) Support from all stakeholders; 5) Vaccination for educators. The above decision is a clear national challenge, especially for the head of the madrasa as an education provider in preparing meaningful face-to-face learning and still attaching to the safety of madrasa staff and students by complying with health protocols.

Muslimin, Fajrussalam, Syah, and Erihadiana (2021) explained that to let the Face-to-Face Learning process take place optimally and adequately, it is also necessary to pay attention to the supporting elements, namely educational facilities or educational facilities and infrastructure. Educational facilities are equipment and supplies directly used in the educational process, while infrastructure is additional equipment that indirectly supports the implementation of the educational process (Mustari \& Rahman, 2014; Marmoah et al., 2019). Infrastructure in education is the main supporting component that can create a meaningful learning process. The importance of infrastructure as a support for teaching and learning activities emphasizes that the education unit's infrastructure management process is a vital effort (Firmansyah et al., 2018; Hefniy \& Fairus, 2019).

Management itself is a process consisting of planning, organizing, and monitoring carried out within an organization to achieve a goal by utilizing available resources (Siswanto \& Hidayati, 2020). The management of 
educational infrastructure could be defined as the entire procurement process and utilization of components that directly or indirectly support the educational process to achieve effective and efficient educational goals (Latifah et al., 2017; Pusvitasari \& Sukur, 2020). In line with this statement, it is explained that the management of facilities and infrastructure is a cooperative mechanism for the effective and efficient use of all educational equipment and is part of the school administration, including planning, pre-qualification, procurement, storage, maintenance, removal, and control (Bafadal, 2004).

The five activities were then narrowed down by Rahmayani (2020) into planning, procurement, organization, and maintenance. In line with this, in Decree No. 20 of 2003 concerning the National Education System, it is explained that the management of facilities and infrastructure is the responsibility of each madrasa/school. Siswanto and Hidayati (2020) demonstrated that the head of the madrasa is responsible for the planning, management, and maintenance of facilities and infrastructure. As part of education management, facilities and infrastructure that are fulfilled and well equipped could create a more comfortable learning environment. However, in the realization process, reasonable control of infrastructure is highly required as in this pandemic situation, the category of quality infrastructure must also meet the health protocol requirements. Therefore, in addition to a comfortable learning process, the safety of madrasa residents can be well guaranteed. With the application of appropriate health protocols and supported by adequate infrastructure, it is hoped that face-to-face learning can be carried out according to the plan and minimize parents' worries in releasing their children to return to school (Fauzi, 2018).

This study explores and analyzes the infrastructure management that follows the health protocol carried out by the head of the madrasa before implementing face-to-face learning during the pandemic at MI Soebono Mantofani, Ciputat, South Tangerang City.

\section{RESEARCH METHODS}

This research was qualitative descriptive research with the type of case study where the researcher conducted an in-depth and specific exploration of a particular event (or several events) of a phenomenon. The research was conducted at MI Soebono Mantofani, which is located in Ciputat, South Tangerang City. The data collection methods of this study were observation, interviews, and documentation, while the subjects in this study were the head of the madrasa, teachers, and administrative staff.

The interview instrument regarding the management of MI Soebono Mantofani's infrastructure in implementing health protocols during the pandemic consisted of four points, namely: 1) Planning for MI Soebono Mantofani's infrastructure facilities in implementing health protocols during the pandemic; 2) Procurement of infrastructure for MI Soebono Mantofani in implementing health protocols during the pandemic; 3) Organising MI Soebono Mantofani's facilities and infrastructure in implementing health protocols during the pandemic, and; 4) Maintenance of MI Soebono 
Mantofani's facilities and infrastructure in implementing health protocols during the pandemic:

The instrument for observing infrastructure management at MI Soebono Mantofani is shown in Table 1.

Table 1 : Observation Instruments of MI Soebono Mantofani

\begin{tabular}{ll}
\hline \multicolumn{1}{c}{ Focus Observation } & \multicolumn{1}{c}{ Things to Observe } \\
\hline Institution-owned facilities and & Facilities and infrastructure to \\
infrastructure & $\begin{array}{l}\text { support health protocols during a } \\
\text { pandemic }\end{array}$ \\
\hline
\end{tabular}

The research data obtained were then processed and analyzed using the data analysis model by Miles, Huberman, and Saldana (2014), which includes three steps, namely; a) data reduction, b) data display, and; c) conclusion drawing/verification. The components of data reduction and data presentation were carried out simultaneously with the data collection process. After the data were collected, the three parts of the analysis (data reduction, data presentation, conclusion drawing) were combined to analyze further.

\section{RESULTS AND DISCUSSION}

\section{Mitigation of Face-to-face Learning in The New Normal Era at MI Soebono Mantofani}

Through the Ministry of Education and Culture, the government has released a statement regarding the requirements that schools/madrasah must carry out before implementing face-to-face learning during the pandemic. These conditions were established so that the learning process could run safely, comfortably, and meaningfully. In addition, the safety and health of teachers/educators and students is the most prioritized thing. MI Soebono Mantofani, in this case, had prepared the implementation of these conditions.

From the interview results, the first step taken was on March 16, 2021, MI Soebono Mantofani coordinated with the South Tangerang Covid-19 Task Force to find out what things must be prepared for face-to-face learning in the New Habit Adaptation era. This is done so that the madrasa's infrastructure planning stage met the health provisions and protocols required by the government. Furthermore, on March 19, 2021, Madrasa stakeholders participated in the vaccination program from the nearest health center; the madrasa, teachers, TU staff, to the security and cleaning officers participated in the vaccination. All madrasa residents had certainly followed the vaccination program so that the face-to-face learning, which was planned for July 2021, can be implemented. Furthermore, the madrasa carefully prepared a checklist of educational facilities according to the standards set by the government to conduct face-to-face learning. This was done to comply with health protocols. Finally, the last one was waiting for permission from the authoritative stakeholders such as the Regional Government, Ministry of Religious Affair, the Head of Madrasa, and representatives of parents through the Committee. 
The support from all related stakeholders was evident. All of these stakeholders together provided positive feedback for face-to-face learning. The madrasa committee also actively offered a significant amount of advice and considerations regarding the preparation of madrasas in face-to-face education. Similar action was also done by the principal and teachers, who were proactive in preparing all the requirements for face-to-face learning and planning the technical form of face-to-face learning to be carried out. Lastly, the role of parents of MI Soebono Mantofani students was supportive in giving approval and providing direction (implementation of health protocols) for their children in the face-to-face learning implementation plan.

MI Soebono Mantofani applied the strategies described by Viner and colleagues (2021) in preparing for face-to-face meetings at madrasa; 1) We are reopening madrasa gradually by implementing a shifting system adjusted to the maximum number of students in one school/class, namely $25 \%$ of students per class or 15-20 students; 2) We are implementing social distancing both outside the madrasa and inside the madrasa and applying this rule to all madrasa residents; 3) Conducting infection control, test, and trace, if there are indications that school residents have been exposed to Covid-19; 4) Protecting teachers and students who are vulnerable such as older-aged teachers and students who have congenital diseases; 5) We are conducting research and evaluation.

\section{Infrastructure Planning at MI Soebono Before Face-to-face Meeting}

The earliest step of providing educational infrastructure is planning. Planning is a framework of any activities which will be done in the future. In a complete expression, planning can be illustrated as the process of careful estimation and assignment of things that will be done in the future to reach specific objectives (Ristianah, 2018). The process of infrastructure planning at MI Soebono Mantofani was done during the meeting involving the school management, the teachers, the madrasa committee, and the foundation members. The panel discussed the following: the evaluation of the available infrastructure, establishment of procurement of infrastructures with consideration on the priority scale, and implementation of a plan through the procurement of the infrastructure needed. For the 2020-2021 academic year, the planning was focused on the infrastructure to support the learning process by the health protocol

The three steps of infrastructure planning close to face-to-face learning were as follows: a) Needs analysis through analyzing and evaluating the infrastructure needed to support in-class and out-of-class learning; b) Funding analysis to suit the needs regarding the purchase of infrastructure, and; c) Priority analysis through choosing the crucial points or more urgent things to be fulfilled first (Nasrudin \& Maryadi, 2018; Dakir \& Fauzi, 2020; Muslimin et al., 2021).

MI Soebono Mantofani was swiftly preparing the infrastructures to support face-to-face learning during the pandemic with several terms, such as; a) Arranging students' seats with 1.5-2 meter spaces and filled with only $25 \%$ of 
the average capacity or a maximum of 15 to 20 students; b) Deciding the number of days and hours of face-to-face learning through division of shifts decided by the madrasa while still prioritizing the health and safety of the madrasa people; c) Placing students in the same dress; d) Not opening the canteen to operate so that all people were advised to bring their food or drinks with a balanced nutritional menu; e) Preparing washstands and hand sanitizers in each classroom; f) Preparing extra masks at the security post to prepare for students who are not wearing masks; g) Preparing thermogenic at the security post to check students' temperatures before entering the madrasa; h) Spraying disinfectant regularly; i) Providing sanitary and hygiene facilities such as clean toilets. Currently, MI Soebono Mantofani has 32 bathrooms for 517 students, which is in line with Permendiknas No. 40 the year 2008; j) Applying maskrequired area throughout the madrasa.

Based on the study's findings conducted at MI Soebono Mantofani, the researcher could generate some pictures in the following. First, according to the needs analysis, which has been adjusted to the required terms, MI Soebono Mantofani registered the central infrastructure needed for the face-to-face learning during the pandemic by the health protocol set by the government, such as clean classrooms, clean tables and chairs, clean canteen to be utilized in the new habit period, washstands and hand sanitizers, thermogenic, masks, sprayer and disinfectant, and sanitation and hygiene facilities. After that, the budget planning arrangement for the infrastructure cost at MI Soebono Mantofani was discussed in detail with the madrasa management, the committee, and the foundation, then arranged according to the mutual agreement. The procurement of educational infrastructures was done through a careful planning process and was administered in an orderly manner so that every use of funds related to this matter can be held accountable to all stakeholders, be it to the government, to the foundation, and the public (Ananda \& Banurea, 2017).

Furthermore, the main priority of the fulfillment of infrastructure at MI Soebono Mantofani during the pandemic was to fulfill the learning infrastructure advised by the government by the health protocol. On the other hand, the additional infrastructure to support learning that is still in good condition and can still be used was only maintained in terms of cleanliness. This was done as a form of efficiency in financial expenditure and procurement of educational facilities or educational infrastructures. Gunawan and Benty (2017) explained that deciding the priority of infrastructure planning is an important thing that should be paid attention to before the procurement is realized. In addition to fulfilling the madrasa's needs in fulfilling the learning process, the priority analysis is also intended to reduce the cost of procuring the infrastructure which still has usability (Nasrudin \& Maryadi, 2018)

\section{Procurement of Infrastructure at MI Soebono Mantofani Prior to Face-to-face Learning}

The Directorate of the Education Staff Development explained that the procurement of madrasa facilities is an activity to procure madrasa infrastructures by adjusting the needs and the previously developed plans. The 
infrastructure procurement procedure should also be based on a guidebook from the Directorate of Education Staff Development, as follows; a) Analysing the needs of infrastructure based on the functions of each item; b) Classifying the infrastructure based on the needs for which the item will be procured; c) Creating and designing a procurement proposal intended to the relevant stakeholders concerned with the proposal submission; d) Conducting an observation which will be done by the authority to assess whether or not the school is worthy of getting infrastructures, and; e) Receiving the items upon the completion of the assessment.

In their study, Nasrudin and Maryadi (2018) explained the four steps of educational infrastructure procurement; arrangement, procurement source, infrastructure quality, and infrastructure functions. The infrastructure procurement at MI Soebono Mantofani was programmed based on the infrastructure planning as discussed during the meeting. The process of infrastructure procurement at MI Soebono Mantofani began with the arrangement done by all stakeholders involved by referring to the preparation results (need analysis, funding analysis, and priority analysis), prioritizing the most urgent one to support learning.

The second step in the procurement process is the procurement source. Taylor, Gronbreg, and Jansen (2011) explained that the source of funds for educational infrastructure procurement could be from the government and private stakeholders with direct involvement with educational institutions. In line with that, the head of funds for infrastructure procurement at MI Soebono Mantofani came from the students' tuition and school operational support funds. The arrangement of fund allocation was made in line with the urgency of the needs. During the pandemic, the fund allocation was used to purchase infrastructure, which was in line with the health protocol to support learning during the pandemic. Martin and Fuad (2016) offered some alternatives of infrastructure procurement through buying, asking for grants, renting, borrowing, recycling, exchanging, repairing, or reconstructing. In this case, the infrastructure procurement at MI Soebono Mantofani referred to the planning results, namely buying/providing infrastructure, which was considered the main priority for the learning process during the pandemic.

The third step in infrastructure procurement is infrastructure quality. Gunawan and Benty (2017) stated that infrastructure procurement should reach the target, be it physical, financial, or benefits for smooth learning. This is done to ensure the infrastructure can perform maximally and effectively and can be used optimally in a long period to minimize the operational budget. The infrastructure to support face-to-face learning during the pandemic was then purchased with attention paid to the quality, such as the thermogenic, hand sanitizer, washstands, and disinfectant.

The fourth step in infrastructure procurement was the infrastructure function. The procurement of educational infrastructure should aim to fulfill the school's needs. The infrastructure should function effectively because educational infrastructure procurement should be in line with the requirements that have been discussed and can give the maximum benefits to the learning 
process (Alimi et al., 2012; Gunawan \& Benty, 2017). The infrastructure procurement at MI Soebono Mantofani in the 2020-2021 academic year was focused on the infrastructure to support learning during the pandemic but still complying with the health protocol.

\section{Soebono Mantofani's Infrastructure Facility organization before face-to- face learning}

Organizing facilities and infrastructure is a process to explain in detail the purpose of the presence of facilities and infrastructure and give responsibility to the people who have been given the task as the person in charge that has been structured (Gunawan \& Benty, 2017). In this case, the Head of Madrasah MI Soebono Mantofani was responsible for organizing infrastructure. This was conducted by giving authority or duties to the administrative staff in storing and inventorying the infrastructure. As the faceto-face learning process has not yet started, the infrastructure (for example, hand sanitizer, thermo gun, and masks) provided for implementing the procedure were stored in the warehouse. Meanwhile, washstands were provided in each classroom. An infrastructure storage system was carried out so that existing facilities were not damaged before being used. Inventorying activities were also carried out to improve the management and adequate supervision of the infrastructure owned by the madrasah.

Inventorying is an activity carried out to improve the management and adequate supervision of facilities and infrastructure owned by schools (Darmastuti, 2014; Sairi \& Safrizal, 2018; Alfina \& Anwar, 2020). Inventorying activities for educational infrastructure include; 1) Registering and making codes for the goods and; 2) Making reports (Bafadal, 2011). Based on the research findings at MI Soebono Mantofani, it was found that: 1) Inventorying was carried out by administrative staff who precisely handled the infrastructure inventorying activities, and; 2) Inventory implementation, namely registering all goods, recording usage condition reports and recapitulating for one year, including new infrastructure facilities, aimed at supporting the process learning by health protocols during a pandemic.

\section{Maintenance of MI Soebono Mantofani's Infrastructure Before Face-to-face Learning}

Maintenance of infrastructure includes continuous and consistent efforts to ensure that infrastructure is in good condition. Martin and Fuad (2016) describe four types of care in terms of their nature: checking maintenance, preventive maintenance, repair maintenance, and heavy maintenance. Care based on time can be done every day (every time or after using) and periodically or within a certain period (Gunawan, 1996). So that the infrastructure is always in good condition, it is necessary to check every infrastructure owned by the madrasah. This check is to see if the state of the infrastructure is in good condition or if it needs to be repaired. 
Table 2 : Lists of MI Soebono Mantofani's Infrastructure before Face-to-face Learning

\begin{tabular}{lcc}
\hline \multicolumn{1}{c}{ Facility } & Amount & Condition \\
\hline Classroom & 18 & Good \\
Library & 3 & Good \\
Headmaster's Office & 1 & Good \\
Teacher's Office & 1 & Good \\
Male teacher's bathroom & 5 & Good \\
Female teacher's bathroom & 5 & Good \\
Male student's bathroom & 16 & Good \\
Female student's bathroom & 16 & Good \\
Warehouse & 2 & Good \\
Sport Field & 3 & Good \\
Canteen & 30 & Good \\
School Health Unit & 1 & Good \\
Washbasin & 10 & Good \\
Hand Sanitizer & 18 Bottles & Good \\
Thermogun & 2 & Good \\
Disinfectant and Spraying Tools & 1 & Good \\
Mask & 20 packs & Good \\
\hline
\end{tabular}

Based on the table above, the infrastructure owned by MI Soebono Mantofani could be categorized as relatively complete and in good condition. The existing classrooms were by the number of current groups. For face-to-face learning plans during the pandemic, which allows classes to be filled by about $25 \%$ of the total number of students, it will not interfere with the learning process due to the distribution of scheduled shifts. All parts of the madrasa building were in good condition and other supporting facilities such as tables and chairs. The arrangement of the tables and chairs in the room had been adjusted to the provisions of physical distancing. Washstands were placed in each classroom and some strategic places. As face-to-face learning had not yet commenced, some infrastructure such as masks, hand sanitizers, disinfectants and sprayers, and thermo guns were stored in the warehouse. Maintenance activities were carried out to ensure every facility and infrastructure was always ready to use in teaching and learning activities (Gunawan, 1996).

\section{CONCLUSION}

From the results and discussion above, it can be concluded that the management of MI Soebono Mantofani's infrastructure before face-to-face learning had been well carried out. Planning for facilities and infrastructure prior to face-to-face learning during the pandemic at MI Soebono Mantofani was carried out by conducting analysis needs. The results would be compiled for internal discussion with relevant stakeholders. Furthermore, procurement of facilities and infrastructure at MI Soebono Mantofani by existing procedures based on the needs analysis and cost estimation. In addition, the organization of 
facilities and infrastructure at MI Soebono Mantofani had also been by the principal's decision by giving authority to the administrative staff to be responsible for existing facilities and infrastructure to maintain facilities and infrastructure at MI Soebono Mantofani would be accountable.

With the preparation of good infrastructure, it was hoped that the faceto-face learning process during the pandemic would be running well so that the risk of having "Lost of Learning" due to social distancing could be overcome immediately.

This study had discussed several issues related to infrastructure management in a school in South Tangerang. It was hoped that this article could contribute to scientific discussions related to the topic and be considered by relevant policymakers. Moreover, this study also acknowledged some limitations which future researchers could explore. For example, this study had a fairly specific scope because it was only conducted in one school. Future researchers could certainly develop it with a broader range. Besides, due to limited access to working data collection, such as limited observation time and some privacy policies regarding documentation for some locations, future researchers could also contribute to scientific discussions on this topic by having better factual data.

\section{REFERENCES}

Alfina, A., \& Anwar, R. N. (2020). Manajemen Sekolah Ramah Anak Paud Inklusi. Al-Tanzim: Jurnal Manajemen Pendidikan Islam, 4(1), 36-47. https://doi.org/10.33650/al-tanzim.v4i1.975

Alimi, O. S., Ehinola, G. B., \& Alabi, F. O. (2012). School types, facilities and academic performance of students in Senior Secondary School in Ondo State, Nigeria. International Education Studies, 5(3), 44-48.

Ananda, R., \& Banurea, O. K. (2017). Manajamen Sarana dan Prasarana Pendidikan. Medan: CV. Widya Puspita.

Bafadal, I. (2004). Manajemen Perlengkapan Sekolah: Teori dan Aplikasinya. Jakarta: Bumi Aksara.

Bafadal, I. (2011). Pengelolaan Perpustakaan Sekolah. Jakarta: Bumi Aksara.

Barnawi, \& Arifin, M. (2012). Manajemen Sarana dan Prasarana Sekolah. Yogyakarta: Ar-Ruzz Media.

Dakir, \& Fauzi, A. (2020). Manajemen Mutu Pendidikan Islam Terpadu. Yogyakarta: Pustaka Pelajar.

Darmastuti, H. (2014). Manajemen Sarana dan Prasarana dalam Upaya Peningkatan Kualitas Pembelajaran pada Jurusan Teknik Komputer dan Informatika di SMK Negeri 2 Surabaya. Jurnal Inspirasi Manajemen Pendidikan, 3(3), 9-20.

Fauzi, A. (2018). Filsafat Manajemen Pendidikan Islam: Mengurai Benang kusut Pengelolaan Pendidikan Islam dari Pendekatan Filosofis Menuju Praktis. Yogyakarta: Pustaka Pelajar. 
Firmansyah, T., Supriyanto, A., \& Timan, A. (2018). Efektivitas Pemanfaatan Sarana dan Prasarana Dalam Meningkatkan Mutu Layanan Di Sma Laboratorium. Jurnal Manajemen Dan Supervisi Pendidikan, 2(3), 179-184. https://doi.org/10.17977/um025v2i32018p179

Gunawan, A. H. (1996). Administrasi Sekolah: Administrasi Pendidikan Mikro. Jakarta: Rineka Cipta.

Gunawan, I., \& Benty, D. D. N. (2017). Manajemen Pendidikan: Suatu Pengantar praktik. Bandung: Alfabeta.

Hefniy, \& Fairus, R. N. (2019). Manajemen Strategi Dalam Meningkatkan Mutu Pelayanan Kepegawaian. Al- Tanzim: Jurnal Manajemen Pendidikan Islam, 3(1), 169-197.

Heryati, Y., \& Muhsin, M. (2014). Manajemen Sumber Daya Pendidikan. Bandung: Pustaka Setia.

Latifah, Purwanti, E., \& Kusuma, N. (2017). Peran Manajemen Keuangan dalam Pengadaan Sarana dan Prasarana Pendidikan di MTs Negeri 2 Pringsewu Kecamatan Banyumas. Jurnal Manajamen Pendidikan Islam, 2(1), 9-14.

Levinson, M., Cevik, M., \& Lipsitch, M. (2020). Reopening primary schools during the pandemic. The New England Journal of Medicine, 383(10), 981985. Retrieved from https:/ / doi.org/10.1056/NEJMms2024920

Marmoah, S., Adela, D., \& Fauziah, M. (2019). Implementation of Facilities and Infrastructure Management in Public Elementary Schools. Al-Tanzim: Jurnal Manajemen Pendidikan Islam, 3(1), 102-134. https://doi.org/10.33650/al-tanzim.v3i1.507

Martin, \& Fuad, N. (2016). Manajemen Sarana dan Prasarana Pendidikan: Konsep dan Aplikasinya. Jakarta: Rajagrafindo Persada.

Miles, M. B., Huberman, A. M., \& Saldana, J. (2014). Qualitative data analysis: A methods sourcebook. California: SAGE Publication.

Muslimin, E., Fajrussalam, H., Syah, M., \& Erihadiana, M. (2021). The implementation of educational facilities and infrastructure management in supporting learning process during pandemic COVID-19: Study at SMA Plus As-Salaam Bandung. Bulletin of Science Education, 1(2), 116-123.

Mustari, M., \& Rahman, M. T. (2014). Manajemen Pendidikan. Jakarta: Raja Grafika Persada.

Nasrudin, \& Maryadi. (2018). Manajemen Sarana dan Prasarana Pendidikan dalam Pembelajaran di SD. Manajemen Pendidikan, 13(1), 15-23.

Onyema, E. M., Eucheria, N. C., Obafemi, F. A., Sen, S., Atonye, F. G., Sharma, A., \& Alsayed, A. O. (2020). Impact of Coronavirus Pandemic on Education. Journal of Education and Practice, 11(13), 108-121. https://doi.org/10.7176/jep/11-13-12

Pusvitasari, R., \& Sukur, M. (2020). Manajemen Keuangan Sekolah dalam Pemenuhan Sarana Prasarana Pendidikan (Studi kasus di SD Muhammadiyah 1 Krian, Sidoarjo). Al-Tanzim: Jurnal Manajemen Pendidikan Islam, 4(1), 94-106. https://doi.org/10.33650/altanzim.v4i1.959 
Rahmayani. (2020). Manajemen Sarana dan Prasarana dalam Meningkatkan Produktivitas di Sekolah Dasar. Edukasi: Jurnal Pendidikan, 18(2), 240-251.

Ristianah, N. (2018). Perencanaan Sarana Prasarana Pendidikan (Studi di PAUD Darush Sholihin Tanjunganom Nganjuk). Intizam: Jurnal Manajemen Pendidikan Islam, 2(1), 64-76.

Sairi, A., \& Safrizal, M. (2018). Pengaruh Mutu Layanan Sarana dan Prasarana Terhadap Kepuasan Siswa. JMKSP (Jurnal Manajemen, Kepemimpinan, Dan Supervisi Pendidikan), 3(1), 20-27.

Siswanto, E., \& Hidayati, D. (2020). Management Indicators of Good Infrastructure Facilities to Improve School Quality. International Journal on Education, Management and Innovation (IJEMI), 1(1), 69-81.

Taylor, L. L., Gronbreg, T. J., \& Jansen, D. W. (2011). The Impact of Facilities on the Cost of Education. National Tax Journal, 64(1), 193-218.

Viner, R. M., Bonell, C., Drake, L., Jourdan, D., Davies, N., Baltag, V., Darzi, A. (2021). Reopening schools during the COVID-19 pandemic: Governments must balance the uncertainty and risks of reopening schools against the clear harms associated with prolonged closure. Archives of Disease in Childhood, 106(2), 111-113. https://doi.org/10.1136/archdischild-2020319963 